\title{
THEORETICAL STUDY ON INTERACTIONS BETWEEN CU-BASED IONIC LIQUID AND PROPANE/PROPYLENE
}

\author{
RENQING L $\ddot{U}^{{ }^{*}+} J I N L^{2} N^{2}$ XIN ZHAO \\ ${ }^{1}$ College of Science, China University of Petroleum (East China), Qingdao, 266580, China \\ ${ }^{2}$ College of Chemical Engineering, China University of Petroleum (East China), Qingdao, 266580, China
}

\begin{abstract}
Density functional theory has been employed to investigate the interactions between copper(I) bis(trifluoromethylsulfonyl)imide $\left(\mathrm{Cu}\left[\mathrm{Tf} \mathrm{N}_{2} \mathrm{~N}\right]\right)$ and $\mathrm{C}_{3} \mathrm{H}_{8} /$ $\mathrm{C}_{3} \mathrm{H}_{6}$. The calculations were based on the model of $\mathrm{Cu}\left[\mathrm{Tf}_{2} \mathrm{~N}\right]$, and performed at X3LYP/6-31++ $\mathrm{G}^{* *}$ level. The calculated interaction energies indicated that the adsorption ability of $\mathrm{Cu}\left[\mathrm{Tf}_{2} \mathrm{~N}\right]$ for $\mathrm{C}_{3} \mathrm{H}_{8} / \mathrm{C}_{3} \mathrm{H}_{6}$ followed the order of $\mathrm{C}_{3} \mathrm{H}_{8}<\mathrm{C}_{3} \mathrm{H}_{6}$. The noncovalent interactions in real space, based on the electron density and its derivatives, reveal the nature of interactions between $\mathrm{Cu}\left[\mathrm{Tf}_{2} \mathrm{~N}\right]$ and $\mathrm{C}_{3} \mathrm{H}_{8} / \mathrm{C}_{3} \mathrm{H}_{6}$. The natural bond orbital $(\mathrm{NBO})$ analysis of the second-order perturbation energy has been performed to investigate the interaction mechanism of $\mathrm{C}_{3} \mathrm{H}_{8} / \mathrm{C}_{3} \mathrm{H}_{6}$ on ionic liquid $\mathrm{Cu}\left[\mathrm{Tf}_{2} \mathrm{~N}\right]$.
\end{abstract}

Key Words: Cu-Based Ionic Liquid, Interaction, $\mathrm{C}_{3} \mathrm{H}_{8} / \mathrm{C}_{3} \mathrm{H}_{6}$

\section{INTRODUCTION}

The recovery of light olefins from the off-gas of catalytic crackers is an important process in the petrochemical industry. Propylene is the raw material for the polypropylene production, a polymer of extensive applications. The separation of olefin/paraffin gas mixtures by low temperature distillation is one of the most important but also most energy-consuming separation processes. Development of economically viable propylene/propane separation processes is becoming increasingly important, but it is extremely challenging due to the physicochemical similarities between those two molecules. Among a number of alternatives separation processes, reactive absorption of olefins from olefin/ paraffin mixtures using a silver salt solution as absorption liquid in a gas/liquid membrane contactor may be attractive in this respect [1-7]. Room temperature ionic liquids are proposed as potential substitutes for conventional solvents as reaction media, such as a negligible volatility, which enables a relatively easy recovery, a wide range of polarities, non-flammable compounds, and high chemical and thermal stability. Besides, their lack of volatility gives ionic liquids the feature that they can perform gas separations without solvent losses or gas stream pollution.

The bis(trifluoromethanesulfonyl)imide (also known as bis(triflyl)imide, $\mathrm{NTf}_{2}^{-}$) salts of the coinage metal ions $\mathrm{Cu}^{+}$and $\mathrm{Ag}^{+}$have been synthesized [810]. It was reported that $\mathrm{Ag}\left[\mathrm{Tf}_{2} \mathrm{~N}\right]$ ionic liquid can be used to separate propane/ propylene or ethylene/ethane $[1,3,11,12]$. Due to the cheap metal of copper and its similar properties in contrast to silver, $\mathrm{Cu}\left[\mathrm{Tf}_{2} \mathrm{~N}\right]$ may be potential to be as sorbent for separation of propane/propylene, so the interactions between $\mathrm{Cu}\left[\mathrm{Tf}_{2} \mathrm{~N}\right]$ and propane/propylene by theoretical methods were compared. The structures of $\mathrm{Cu}\left[\mathrm{Tf}_{2} \mathrm{~N}\right]$, propane, and propylene are shown in Fig. 1.

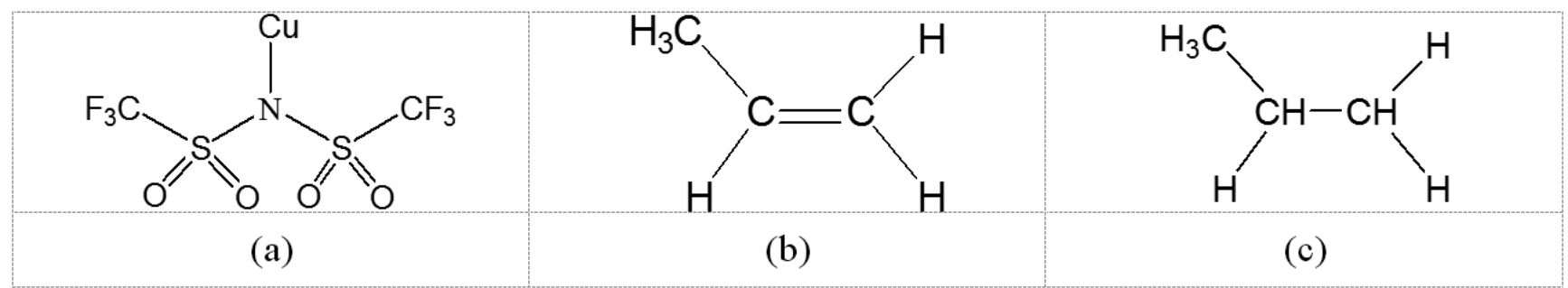

Fig. 1 The structures of (a) $\mathrm{Cu}\left[\mathrm{Tf}_{2} \mathrm{~N}\right]$, (b) $\mathrm{C}_{3} \mathrm{H}_{6}$ and (c) $\mathrm{C}_{3} \mathrm{H}_{8}$

2 Computational details

The extended hybrid density functional X3LYP [13], which is wildly used in ionic liquids $[14,15]$, reveals excellent performance, hence we used this method which is good at describing the van der Waals and hydrogen bonding interactions [16]. The 6-31++G(d,p) basis set (5d, 7f spherical-harmonic type) has been employed in all the calculations since they can give a fine compromise between accuracy and computational cost. No symmetry constraint was imposed on the optimization of initial structures. To examine the nature of interactions, the electronic properties for stationary points were illustrated in terms of natural bond orbital (NBO) analysis [17]. The NBO analysis was obtained with $6-31++\mathrm{G}^{* *}$ basis set to provide information of hydrogen bonding and halogen bonding. Multiwfn softpackage $[18,19]$ was employed to analyze the interaction properties.

For interaction energy, basis set superposition errors (BSSE) were considered using the counterpoise method [20] and the relative energy of certain structure is defined as the difference relative to the most stable structure, which was calculated as following:

\section{RESULTS AND DISCUSSION}

3.1 Geometric, electronic properties and interaction energies

In this section, we discuss the most stable geometries of $\mathrm{Cu}\left[\mathrm{Tf}_{2} \mathrm{~N}\right]-\mathrm{C}_{3} \mathrm{H}_{8}$ and $\mathrm{Cu}\left[\mathrm{Tf}_{2} \mathrm{~N}\right]-\mathrm{C}_{3} \mathrm{H}_{6}$. Fig. 2 shows the two most stable geometries optimized at the X3LYP $/ 6-31++G(d, p)$ level, frequency analyses of all stationary points have been performed with the same level calculations to guarantee the most stable geometries of the molecules. Some important structural parameters, including the distances and $\mathrm{NBO}$ charge between $\mathrm{Cu}\left[\mathrm{Tf}_{2} \mathrm{~N}\right]$ and $\mathrm{C}_{3} \mathrm{H}_{8} / \mathrm{C}_{3} \mathrm{H}_{6}$ are listed. The distances of $\mathrm{Cu} \cdots \mathrm{H} 11, \mathrm{Cu} \cdots \mathrm{H} 12$ and $\mathrm{Cu} \cdots \mathrm{C} 1$ in $\mathrm{Cu}\left[\mathrm{Tf}_{2} \mathrm{~N}\right]-\mathrm{C}_{3} \mathrm{H}_{8}$ are $1.833 \AA, 1.836 \AA$ and $2.157 \AA$, less than the sum of van der Waals radii of $\mathrm{Cu}(1.4 \AA), \mathrm{H}(1.20 \AA)$, and $\mathrm{C}(1.70 \AA)[21]$. While the $\mathrm{Cu} \cdots \mathrm{C} 1$ and $\mathrm{Cu} \cdots \mathrm{C} 2$ distances in $\mathrm{Cu}\left[\mathrm{Tf}_{2} \mathrm{~N}\right]-\mathrm{C}_{3} \mathrm{H}_{6}$ are $2.004 \AA, 2.053 \AA$, respectively, which suggest the strong interactions between $\mathrm{Cu}\left[\mathrm{Tf}_{2} \mathrm{~N}\right]$ and $\mathrm{C}_{3} \mathrm{H}_{6}$.

The interaction energies between $\mathrm{Cu}\left[\mathrm{Tf}_{2} \mathrm{~N}\right]$ and $\mathrm{C}_{3} \mathrm{H}_{8} / \mathrm{C}_{3} \mathrm{H}_{6}$ were 18.63 $\mathrm{Kcal} / \mathrm{mol}$ and $40.16 \mathrm{Kcal} / \mathrm{mol}$, respectively, demonstrating that the interaction between $\mathrm{Cu}\left[\mathrm{Tf}_{2} \mathrm{~N}\right]$ and $\mathrm{C}_{3} \mathrm{H}_{8}$ is weaker than that between $\mathrm{Cu}\left[\mathrm{Tf}_{2} \mathrm{~N}\right]$ and $\mathrm{C}_{3} \mathrm{H}_{6}$. 


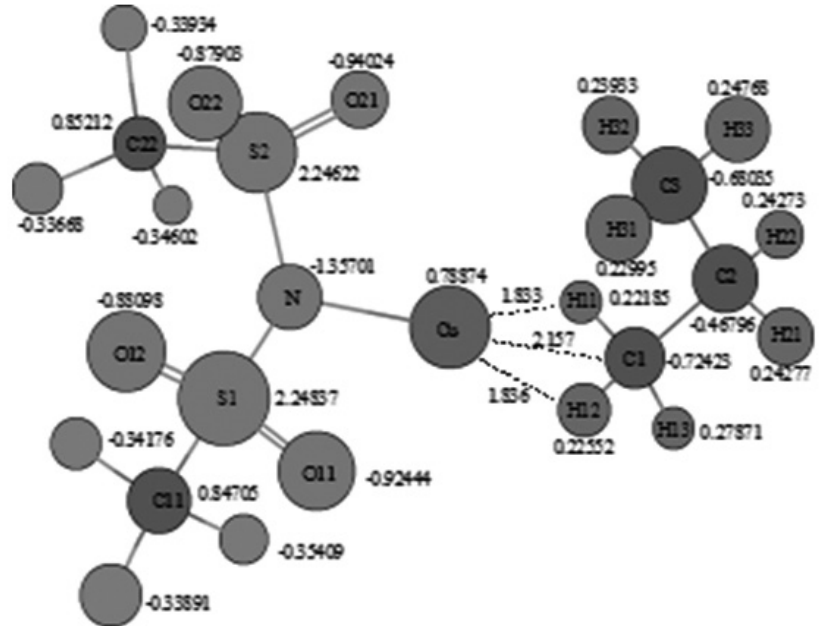

(a)

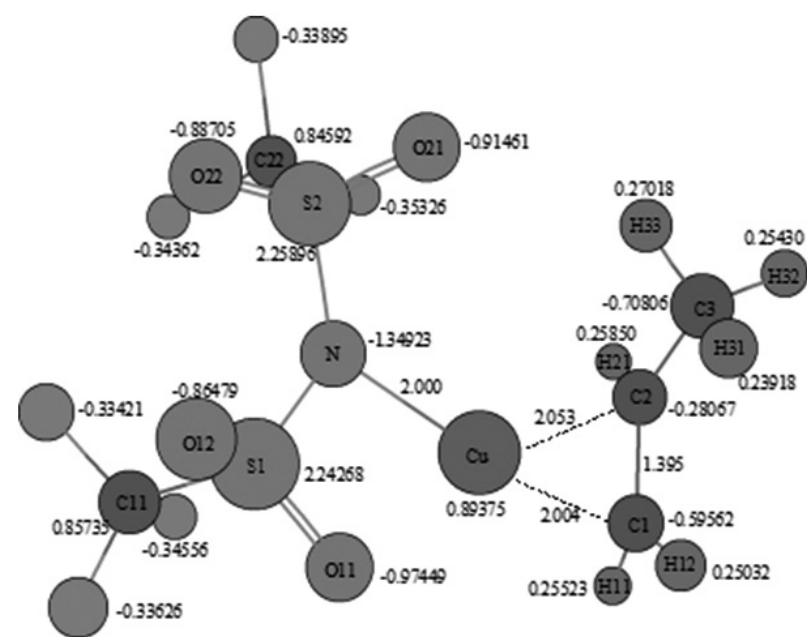

(b)

Fig. 2 The optimized structures and NBO charge of (a) $\mathrm{Cu}\left[\mathrm{Tf}_{2} \mathrm{~N}\right]-\mathrm{C}_{3} \mathrm{H}_{8}$ and (b) $\mathrm{Cu}\left[\mathrm{Tf}_{2} \mathrm{~N}\right]-\mathrm{C}_{3} \mathrm{H}_{6}$

\subsection{NBO analysis}

The optimized structures were employed for NBO analysis. NBO analysis is based on a method for optimally transforming a given wave function into localized form, corresponding to the one-center (lone pairs) and two-center (bonds) elements of the chemist's Lewis structure picture. It provides a better description of the electron distribution in complexes. The NBO analysis were performed for $\mathrm{Cu}\left[\mathrm{Tf} \mathrm{N}_{2}-\mathrm{C}_{3} \mathrm{H}_{8}\right.$ and $\mathrm{Cu}\left[\mathrm{Tf}_{2} \mathrm{~N}\right]-\mathrm{C}_{3} \mathrm{H}_{6}$. The $\mathrm{NBO}$ charges (Fig. 2) of $\mathrm{N}$ and $\mathrm{Cu}$ in $\mathrm{Cu}\left[\mathrm{Tf}_{2}^{2} \mathrm{~N}\right]-\mathrm{C}_{3} \mathrm{H}_{8}$ and $\mathrm{Cu}\left[\mathrm{Tf}_{2}^{2} \mathrm{~N}\right]-\mathrm{C}_{3} \mathrm{H}_{6}$ are $-1.35701,0.78874$, and $-1.34923,0.89375$, respectively, suggesting that the more negative charges of $\mathrm{H} 11$ and $\mathrm{H} 12$ migrate to $\mathrm{Cu}$ in $\mathrm{Cu}\left[\mathrm{Tf}_{2} \mathrm{~N}\right]-\mathrm{C}_{3} \mathrm{H}_{8}$ and the more positive $\mathrm{Cu}$ in $\mathrm{Cu}\left[\mathrm{Tf}_{2} \mathrm{~N}\right]-\mathrm{C}_{3} \mathrm{H}_{6}$ may be ascribed to its back-donation.

Table 1 gives the natural electron configurations of $\mathrm{Cu}, \mathrm{N}, \mathrm{S} 2, \mathrm{~S} 1$, $\mathrm{H} 11, \mathrm{H} 12$ or $\mathrm{C} 1, \mathrm{C} 2$ of $\mathrm{Cu}\left[\mathrm{Tf}_{2} \mathrm{~N}\right]-\mathrm{C}_{3} \mathrm{H}_{8}$ and $\mathrm{Cu}\left[\mathrm{Tf}_{2} \mathrm{~N}\right]-\mathrm{C}_{3} \mathrm{H}_{6}$. The electron configurations of copper in $\mathrm{Cu}\left[\mathrm{Tf}_{2} \mathrm{~N}\right]-\mathrm{C}_{3} \mathrm{H}_{8}$ and $\mathrm{Cu}\left[\mathrm{Tf} \mathrm{N}_{2} \mathrm{~N}-\mathrm{C}_{3} \mathrm{H}_{6}\right.$ are [core] $3 \mathrm{~d}^{9.84} 4 \mathrm{~s}^{0.35} 4 \mathrm{~d}^{0.01} 5 \mathrm{p}^{0.01}$ and [core] $3 \mathrm{~d}^{9.74} 4 \mathrm{~s}^{0.35} 4 \mathrm{~d}^{0.01} 5 \mathrm{p}^{0.01}$, respectively, indicating the more decreasing of $3 \mathrm{~d}$ orbital electrons of $\mathrm{Cu}\left[\mathrm{Tf}_{2} \mathrm{~N}\right]-\mathrm{C}_{3} \mathrm{H}_{6}$ in contrast to that of $\mathrm{Cu}\left[\mathrm{Tf}_{2} \mathrm{~N}\right]-\mathrm{C}_{3} \mathrm{H}_{6}$. The $\mathrm{C} 1$ and $\mathrm{C} 2$ electron configurations in $\mathrm{Cu}\left[\mathrm{Tf}_{2} \mathrm{~N}\right]-\mathrm{C}_{3} \mathrm{H}_{6}$ are [core] $2 \mathrm{~s}^{1.09} 2 \mathrm{p}^{3.48} 4 \mathrm{~s}^{0.01} 4 \mathrm{p}^{0.01}$ and [core] $2 \mathrm{~s}^{1.02} 2 \mathrm{p}^{3.23} 4 \mathrm{~s}^{0.01} 4 \mathrm{p}^{0.02}$, respectively, demonstrating the net electron migration from copper to $\mathrm{C} 1$ and $\mathrm{C} 2$.

The linear combination of natural atomic orbitals (NAOs) of $\mathrm{Cu}\left[\mathrm{Tf}_{2} \mathrm{~N}\right]-$ $\mathrm{C}_{3} \mathrm{H}_{8}$ and $\mathrm{Cu}\left[\mathrm{Tf}_{2} \mathrm{~N}\right]-\mathrm{C}_{3} \mathrm{H}_{6}$ are tabulated in Table 2. It can be seen the fact that the occupancy for $\mathrm{LP}(5) \mathrm{Cu}(3 \mathrm{~d})$ and $\mathrm{LP} *(6) \mathrm{Cu}(4 \mathrm{~s})$ in $\mathrm{Cu}\left[\mathrm{Tf}_{2} \mathrm{~N}\right]-\mathrm{C}_{3} \mathrm{H}$ and $\mathrm{Cu}\left[\mathrm{Tf}_{2} \mathrm{~N}\right]-\mathrm{C}_{3} \mathrm{H}_{6}$ are $1.97755,0.25213$ and $1.81391,0.29997$ is remarkably different, implying the more charge transfer of $3 \mathrm{~d}$ orbital from $\mathrm{Cu}\left[\mathrm{Tf}_{2} \mathrm{~N}\right]$ to $\mathrm{C}_{3} \mathrm{H}_{6}$ and more charge back donation to $4 \mathrm{~s}^{*}$ orbital of $\mathrm{Cu}\left[\mathrm{Tf}_{2} \mathrm{~N}\right]$ from $\mathrm{C}_{3} \mathrm{H}_{6}$. The occupancy of $\sigma^{*}(\mathrm{C} 1-\mathrm{H} 13), \sigma^{*}(\mathrm{C} 1-\mathrm{H} 12)$, and $\sigma^{*}(\mathrm{C} 1-\mathrm{H} 11)$ indicates the charge transfer to anti-orbital of $\mathrm{C}_{3} \mathrm{H}_{8}$, while the occupancy of $\sigma(\mathrm{C} 1-\mathrm{C} 2), \pi(\mathrm{C} 1-\mathrm{C} 2)$, $\sigma^{*}(\mathrm{C} 1-\mathrm{C} 2)$ and $\pi^{*}(\mathrm{C} 1-\mathrm{C} 2)$ is $1.99157,1.83797,0.01166$ and 0.23584 , demonstrating the main charge transfer between $\mathrm{Cu}\left[\mathrm{Tf}_{2} \mathrm{~N}\right]$ and $\pi(\mathrm{C} 1-\mathrm{C} 2)$, $\pi^{*}(\mathrm{C} 1-\mathrm{C} 2)$ orbitals of $\mathrm{C}_{3} \mathrm{H}_{6}$.

Table 1 The natural electron configurations of $\mathrm{Cu}, \mathrm{N}, \mathrm{S} 2, \mathrm{~S} 1, \mathrm{H} 11, \mathrm{H} 12$ or $\mathrm{C} 1, \mathrm{C} 2$ of $\mathrm{Cu}\left[\mathrm{Tf}_{2} \mathrm{~N}\right]-\mathrm{C}_{3} \mathrm{H}_{8}$ and $\mathrm{Cu}\left[\mathrm{Tf}_{2} \mathrm{~N}\right]-\mathrm{C}_{3} \mathrm{H}_{6}$

\begin{tabular}{|c|c|c|c|}
\hline \multicolumn{2}{|c|}{$\mathrm{Cu}\left[\mathrm{Tf}_{2} \mathrm{~N}\right]-\mathrm{C}_{3} \mathrm{H}_{8}$} & \multicolumn{2}{c|}{$\mathrm{Cu}\left[\mathrm{Tf}_{2} \mathrm{~N}\right]-\mathrm{C}_{3} \mathrm{H}_{6}$} \\
\hline $\mathrm{Cu}$ & {$[$ core $] 3 \mathrm{~d}^{9.84} 4 \mathrm{~s}^{0.35} 4 \mathrm{~d}^{0.01} 5 \mathrm{p}^{0.01}$} & $\mathrm{Cu}$ & {$[$ core $] 3 \mathrm{~d}^{9.74} 4 \mathrm{~s}^{0.35} 4 \mathrm{~d}^{0.01} 5 \mathrm{p}^{0.01}$} \\
\hline $\mathrm{N}$ & {$[$ core $] 2 \mathrm{~s}^{1.61} 2 \mathrm{p}^{4.72} 3 \mathrm{~s}^{0.01} 3 \mathrm{p}^{0.02}$} & $\mathrm{~N}$ & {$[$ core $] 2 \mathrm{~s}^{1.61} 2 \mathrm{p}^{4.71} 3 \mathrm{~s}^{0.01} 3 \mathrm{p}^{0.02}$} \\
\hline $\mathrm{S} 2$ & {$[$ core $] 3 \mathrm{~s}^{1.08} 3 \mathrm{p}^{2.47} 3 \mathrm{~d}^{0.17} 4 \mathrm{p}^{0.01} 5 \mathrm{~s}^{0.01} 5 \mathrm{p}^{0.02}$} & $\mathrm{~S} 2$ & {$[$ core $] 3 \mathrm{~s}^{1.07} 3 \mathrm{p}^{2.46} 3 \mathrm{~d}^{0.1} 4 \mathrm{p}^{0.02} 5 \mathrm{~s}^{0.01} 5 \mathrm{p}^{0.01}$} \\
\hline $\mathrm{S} 1$ & {$[$ core $] 3 \mathrm{~s}^{1.08} 3 \mathrm{p}^{2.47} 3 \mathrm{~d}^{0.17} 4 \mathrm{p}^{0.02} 5 \mathrm{~s}^{0.01} 5 \mathrm{p}^{0.01}$} & $\mathrm{~S} 1$ & {$[$ core $] 3 \mathrm{~s}^{1.08} 3 \mathrm{p}^{2.47} 3 \mathrm{~d}^{0.16} 4 \mathrm{p}^{0.03} 5 \mathrm{~s}^{0.01}$} \\
\hline $\mathrm{H} 11$ & $1 \mathrm{~s}^{0.77}$ & $\mathrm{C} 1$ & {$[$ core $] 2 \mathrm{~s}^{1.09} 2 \mathrm{p}^{3.48} 4 \mathrm{~s}^{0.01} 4 \mathrm{p}^{0.01}$} \\
\hline $\mathrm{H} 12$ & $1 \mathrm{~s}^{0.77}$ & $\mathrm{C} 2$ & {$[$ core $] 2 \mathrm{~s}^{1.02} 2 \mathrm{p}^{3.23} 4 \mathrm{~s}^{0.01} 4 \mathrm{p}^{0.02}$} \\
\hline
\end{tabular}

Table 2 The linear combination of natural atomic orbitals (NAOs) of $\mathrm{Cu}\left[\mathrm{Tf}_{2} \mathrm{~N}\right]-\mathrm{C}_{3} \mathrm{H}_{8}$ and $\mathrm{Cu}\left[\mathrm{Tf}_{2} \mathrm{~N}\right]-\mathrm{C}_{3} \mathrm{H}_{6}$

\begin{tabular}{|c|c|c|c|c|c|}
\hline \multicolumn{3}{|c|}{$\mathrm{Cu}\left[\mathrm{Tf}_{2} \mathrm{~N}\right]-\mathrm{C}_{3} \mathrm{H}_{8}$} & \multicolumn{2}{c|}{$\mathrm{Cu}_{2}\left[\mathrm{Tf}_{2} \mathrm{~N}\right]-\mathrm{C}_{3} \mathrm{H}_{6}$} \\
\hline $\mathrm{NBO}$ & occupancy & $\mathrm{NAO}$ & $\mathrm{NBO}$ & occupancy & NAO \\
\hline $\mathrm{LP}(1) \mathrm{Cu}$ & 1.99900 & $3 \mathrm{~d}$ & $\mathrm{LP}(1) \mathrm{Cu}$ & 1.99769 & $3 \mathrm{~d}$ \\
\hline $\mathrm{LP}(2) \mathrm{Cu}$ & 1.99746 & $3 \mathrm{~d}$ & $\mathrm{LP}(2) \mathrm{Cu}$ & 1.99656 & $3 \mathrm{~d}$ \\
\hline $\mathrm{LP}(3) \mathrm{Cu}$ & 1.98856 & $3 \mathrm{~d}$ & $\mathrm{LP}(3) \mathrm{Cu}$ & 1.99076 & $3 \mathrm{~d}$ \\
\hline $\mathrm{LP}(4) \mathrm{Cu}$ & 1.97873 & $3 \mathrm{~d}$ & $\mathrm{LP}(4) \mathrm{Cu}$ & 1.98905 & $3 \mathrm{~d}$ \\
\hline $\mathrm{LP}(5) \mathrm{Cu}$ & 1.97755 & $3 \mathrm{~d}$ & $\mathrm{LP}(5) \mathrm{Cu}$ & 1.81391 & $3 \mathrm{~d}$ \\
\hline $\mathrm{LP}(6) \mathrm{Cu}$ & 0.25213 & $4 \mathrm{~s}$ & $\mathrm{LP}(6) \mathrm{Cu}$ & 0.29997 & $4 \mathrm{~s}$ \\
\hline$\sigma^{*}(\mathrm{C} 1-\mathrm{H} 13)$ & 0.00948 & $0.5595\left(\mathrm{sp}^{3.05}\right)_{\mathrm{C} 1}-0.8004(\mathrm{~s})_{\mathrm{H} 13}$ & $\sigma(\mathrm{C} 1-\mathrm{C} 2)$ & 1.99157 & $0.7034\left(\mathrm{sp}^{1.95}\right)_{\mathrm{C} 1}+0.7108\left(\mathrm{sp}^{1.93}\right)_{\mathrm{C} 2}$ \\
\hline$\sigma^{*}(\mathrm{C} 1-\mathrm{H} 12)$ & 0.02281 & $0.6230\left(\mathrm{sp}^{3.33}\right)_{\mathrm{Cl}}-0.7822(\mathrm{~s})_{\mathrm{H} 12}$ & $\pi(\mathrm{C} 1-\mathrm{C} 2)$ & 1.83797 & $0.7340\left(\mathrm{sp}^{24.42}\right)_{\mathrm{C} 1}+0.6792\left(\mathrm{sp}^{31.53}\right)_{\mathrm{C} 2}$ \\
\hline$\sigma^{*}(\mathrm{C} 1-\mathrm{H} 11)$ & 0.02259 & $0.6249\left(\mathrm{sp}^{3.36}\right)_{\mathrm{C} 1}-0.7807(\mathrm{~s})_{\mathrm{H} 11}$ & $\sigma *(\mathrm{C} 1-\mathrm{C} 2)$ & 0.01166 & $0.7108\left(\mathrm{sp}^{1.95}\right)_{\mathrm{C} 1}-0.7034\left(\mathrm{sp}^{1.93}\right)_{\mathrm{C} 2}$ \\
\hline & & & $\pi *(\mathrm{C} 1-\mathrm{C} 2)$ & 0.23584 & $0.6792\left(\mathrm{sp}^{24.42}\right)_{\mathrm{C1}}-0.7340\left(\mathrm{sp}^{31.53}\right)_{\mathrm{C} 2}$ \\
\hline
\end{tabular}


Table 3 Some donor-acceptor interactions in $\mathrm{Cu}\left[\mathrm{Tf}_{2} \mathrm{~N}\right]-\mathrm{C}_{3} \mathrm{H}_{8}, \mathrm{Cu}\left[\mathrm{Tf}_{2} \mathrm{~N}\right]-\mathrm{C}_{3} \mathrm{H}_{6}$ and their second order perturbation stabilization energies, $E(2)(\mathrm{kcal} / \mathrm{mol})$

\begin{tabular}{|c|c|c|c|c|c|}
\hline Donor & Acceptor & $E(2)(\mathrm{kcal} / \mathrm{mol})$ & Donor & Acceptor & $E(2)(\mathrm{kcal} / \mathrm{mol})$ \\
\hline \multicolumn{6}{|c|}{$\mathrm{Cu}\left[\mathrm{Tf}_{2} \mathrm{~N}\right]-\mathrm{C}_{3} \mathrm{H}_{8}$} \\
\hline $\mathrm{LP}(2) \mathrm{Cu}$ & $\sigma^{*}(\mathrm{C} 1-\mathrm{H} 12)$ & 0.19 & $\mathrm{LP}(2) \mathrm{Cu}$ & $\sigma^{*}(\mathrm{C} 1-\mathrm{H} 11)$ & 0.16 \\
\hline $\mathrm{LP}(4) \mathrm{Cu}$ & $\sigma^{*}(\mathrm{C} 1-\mathrm{H} 11)$ & 3.39 & $\mathrm{LP}(3) \mathrm{Cu}$ & $\sigma^{*}(\mathrm{C} 1-\mathrm{H} 13)$ & 0.61 \\
\hline $\mathrm{LP}(5) \mathrm{Cu}$ & $\sigma^{*}(\mathrm{C} 1-\mathrm{H} 12)$ & 3.04 & $\mathrm{LP}(4) \mathrm{Cu}$ & $\sigma^{*}(\mathrm{C} 1-\mathrm{H} 12)$ & 0.74 \\
\hline $\mathrm{LP}^{*}(6) \mathrm{Cu}$ & $\sigma^{*}(\mathrm{C} 3-\mathrm{H} 33)$ & 0.17 & $\mathrm{LP}(5) \mathrm{Cu}$ & $\sigma^{*}(\mathrm{C} 1-\mathrm{H} 11)$ & 0.42 \\
\hline $\mathrm{LP}^{*}(6) \mathrm{Cu}$ & $\sigma^{*}(\mathrm{C} 2-\mathrm{C} 1)$ & 0.46 & $\mathrm{LP}^{*}(6) \mathrm{Cu}$ & $\sigma^{*}(\mathrm{C} 3-\mathrm{H} 32)$ & 0.05 \\
\hline $\mathrm{LP} *(6) \mathrm{Cu}$ & $\sigma^{*}(\mathrm{C} 1-\mathrm{H} 11)$ & 0.65 & $\mathrm{LP} *(6) \mathrm{Cu}$ & $\sigma^{*}(\mathrm{C} 1-\mathrm{H} 13)$ & 0.80 \\
\hline$\sigma(\mathrm{C} 3-\mathrm{H} 31)$ & $\mathrm{LP}^{*}(6) \mathrm{Cu}$ & 0.35 & $\mathrm{LP}^{*}(6) \mathrm{Cu}$ & $\sigma^{*}(\mathrm{C} 1-\mathrm{H} 12)$ & 0.59 \\
\hline$\sigma(\mathrm{C} 2-\mathrm{C} 1)$ & $\mathrm{LP} *(6) \mathrm{Cu}$ & 0.18 & $\sigma(\mathrm{C} 3-\mathrm{H} 32)$ & $\mathrm{LP}^{*}(6) \mathrm{Cu}$ & 0.41 \\
\hline$\sigma(\mathrm{C} 2-\mathrm{H} 22)$ & $\mathrm{LP}^{*}(6) \mathrm{Cu}$ & 0.16 & $\sigma(\mathrm{C} 2-\mathrm{H} 21)$ & $\mathrm{LP}^{*}(6) \mathrm{Cu}$ & 0.17 \\
\hline$\sigma(\mathrm{C} 1-\mathrm{H} 12)$ & $\mathrm{LP}^{*}(6) \mathrm{Cu}$ & 19.61 & $\sigma(\mathrm{C} 1-\mathrm{H} 11)$ & $\mathrm{LP} *(6) \mathrm{Cu}$ & 20.19 \\
\hline \multicolumn{6}{|c|}{$\mathrm{Cu}\left[\mathrm{Tf}_{2} \mathrm{~N}\right]-\mathrm{C}_{3} \mathrm{H}_{6}$} \\
\hline $\mathrm{LP}(1) \mathrm{Cu}$ & $\sigma^{*}(\mathrm{C} 3-\mathrm{C} 2)$ & 0.10 & $\mathrm{LP}(3) \mathrm{Cu}$ & $\sigma^{*}(\mathrm{H} 11-\mathrm{C} 1)$ & 0.41 \\
\hline $\mathrm{LP}(2) \mathrm{Cu}$ & $\sigma^{*}(\mathrm{H} 12-\mathrm{C} 1)$ & 0.10 & $\mathrm{LP}(3) \mathrm{Cu}$ & $\sigma^{*}(\mathrm{H} 21-\mathrm{C} 2)$ & 0.24 \\
\hline $\mathrm{LP}(3) \mathrm{Cu}$ & $\sigma^{*}(\mathrm{C} 3-\mathrm{C} 2)$ & 0.22 & $\mathrm{LP}(5) \mathrm{Cu}$ & $\sigma^{*}(\mathrm{H} 11-\mathrm{C} 1)$ & 0.18 \\
\hline $\mathrm{LP}(3) \mathrm{Cu}$ & $\sigma^{*}(\mathrm{H} 12-\mathrm{C} 1)$ & 0.39 & $\mathrm{LP}(5) \mathrm{Cu}$ & $\sigma^{*}(\mathrm{H} 21-\mathrm{C} 2)$ & 0.15 \\
\hline $\mathrm{LP}(5) \mathrm{Cu}$ & $\sigma^{*}(\mathrm{H} 12-\mathrm{C} 1)$ & 0.16 & $\mathrm{LP}(5) \mathrm{Cu}$ & $\pi^{*}(\mathrm{C} 1-\mathrm{C} 2)$ & 28.98 \\
\hline $\mathrm{LP} *(6) \mathrm{Cu}$ & $\sigma^{*}(\mathrm{C} 3-\mathrm{H} 32)$ & 0.14 & $\mathrm{LP} *(6) \mathrm{Cu}$ & $\sigma^{*}(\mathrm{C} 3-\mathrm{C} 2)$ & 0.14 \\
\hline $\mathrm{LP}(\mathrm{N})$ & $\pi^{*}(\mathrm{C} 1-\mathrm{C} 2)$ & 1.33 & $\mathrm{LP}(\mathrm{O} 21)$ & $\sigma^{*}(\mathrm{C} 3-\mathrm{H} 33)$ & 0.72 \\
\hline $\mathrm{LP}(\mathrm{O} 11)$ & $\pi^{*}(\mathrm{C} 1-\mathrm{C} 2)$ & 0.78 & $\sigma^{*}(\mathrm{~S} 2-\mathrm{O} 21)$ & $\sigma^{*}(\mathrm{C} 3-\mathrm{H} 33)$ & 0.17 \\
\hline$\sigma(\mathrm{C} 1-\mathrm{C} 2)$ & $\mathrm{LP}^{*}(6) \mathrm{Cu}$ & 7.48 & $\pi(\mathrm{C} 1-\mathrm{C} 2)$ & $\mathrm{LP}^{*}(6) \mathrm{Cu}$ & 64.82 \\
\hline$\pi(\mathrm{C} 1-\mathrm{C} 2)$ & $\mathrm{RY}^{*}(3) / \mathrm{Cu}$ & 2.37 & $\sigma(\mathrm{C} 1-\mathrm{H} 11)$ & $\mathrm{LP}^{*}(6) \mathrm{Cu}$ & 4.60 \\
\hline$\sigma(\mathrm{C} 1-\mathrm{H} 12)$ & $\mathrm{LP}^{*}(6) \mathrm{Cu}$ & 3.99 & $\sigma(\mathrm{C} 2-\mathrm{C} 3)$ & $\mathrm{LP} *(6) \mathrm{Cu}$ & 2.03 \\
\hline$\sigma(\mathrm{C} 2-\mathrm{H} 21)$ & $\mathrm{LP}^{*}(6) \mathrm{Cu}$ & 3.58 & $\pi^{*}(\mathrm{C} 1-\mathrm{C} 2)$ & $\mathrm{LP}^{*}(6) \mathrm{Cu}$ & 3.11 \\
\hline
\end{tabular}

Some donor-acceptor interactions in $\mathrm{Cu}\left[\mathrm{Tf}_{2} \mathrm{~N}\right]-\mathrm{C}_{3} \mathrm{H}_{8}, \mathrm{Cu}\left[\mathrm{Tf}_{2} \mathrm{~N}\right]-\mathrm{C}_{3} \mathrm{H}_{6}$ and their second order perturbation stabilization energies are given in Table 3. The main interactions in $\mathrm{Cu}\left[\mathrm{Tf}_{2} \mathrm{~N}\right]-\mathrm{C}_{3} \mathrm{H}_{8}$ are $\mathrm{LP}(4) \mathrm{Cu} \rightarrow \sigma^{*}(\mathrm{C} 1-\mathrm{H} 11), \mathrm{LP}(5)$ $\mathrm{Cu} \rightarrow \sigma^{*}(\mathrm{C} 1-\mathrm{H} 12), \quad \sigma(\mathrm{C} 1-\mathrm{H} 12) \rightarrow \mathrm{LP} *(6) \mathrm{Cu}$, and $\sigma(\mathrm{C} 1-\mathrm{H} 11) \rightarrow \mathrm{LP} *(6) \mathrm{Cu}$, exhibiting the strong interactions between $\sigma(\mathrm{C} 1-\mathrm{H} 12), \sigma(\mathrm{C} 1-\mathrm{H} 11)$ and $4 \mathrm{~s}^{*}$ orbital. While the main interactions in $\mathrm{Cu}\left[\mathrm{Tf}_{2} \mathrm{~N}\right]-\mathrm{C}_{3} \mathrm{H}_{6}$ are $\mathrm{LP}(5) \mathrm{Cu} \rightarrow \pi *(\mathrm{C} 1-\mathrm{C} 2)$, $\sigma(\mathrm{C} 1-\mathrm{C} 2) \rightarrow \mathrm{LP} *(6) \mathrm{Cu}, \pi(\mathrm{C} 1-\mathrm{C} 2) \rightarrow \mathrm{LP} *(6) \mathrm{Cu}, \sigma(\mathrm{C} 1-\mathrm{H} 11) \rightarrow \mathrm{LP} *(6) \mathrm{Cu}$ $\sigma(\mathrm{C} 1-\mathrm{H} 12) \rightarrow \mathrm{LP} *(6) \mathrm{Cu}, \sigma(\mathrm{C} 2-\mathrm{C} 3) \rightarrow \mathrm{LP}^{*}(6) \mathrm{Cu}, \sigma(\mathrm{C} 2-\mathrm{H} 21) \rightarrow \mathrm{LP} *(6) \mathrm{Cu}$, $\pi^{*}(\mathrm{C} 1-\mathrm{C} 2) \rightarrow \mathrm{LP} *(6) \mathrm{Cu}$, demonstrating the strong interactions due to charge transfer from $\pi(\mathrm{C} 1-\mathrm{C} 2)$ to $4 \mathrm{~s}^{*}$ and back donation from d orbital to $\pi^{*}(\mathrm{C} 1-\mathrm{C} 2)$. The significant differences between $\mathrm{Cu}\left[\mathrm{Tf}_{2} \mathrm{~N}\right]$ and $\mathrm{C}_{3} \mathrm{H}_{8} / \mathrm{C}_{3} \mathrm{H}_{6}$ are that $\pi(\mathrm{C} 1-\mathrm{C} 2)$ and $\pi^{*}(\mathrm{C} 1-\mathrm{C} 2)$ are involved in the interactions.

3 Visualization of weak interactions with real space functions

Yang and co-workers recently presented a new method for studying non-covalent interactions in and between molecules [22]. The non-covalent interaction analysis is based on considering three components of the electron density distribution: the density itself $(\rho)$, the reduced gradient of the density $\left(s=|\nabla \rho| /\left(2\left(3 \pi^{2}\right)^{1 / 3} \rho^{4 / 3}\right)\right)$, and the Laplacian of the density $\left(\nabla^{2} \rho\right)$. The Laplacian is further decomposed into three eigenvalues $\left(\lambda_{1} \leq \lambda_{2} \leq \lambda_{3}\right)$. The second component, 1 , contains the interesting information; when $\lambda<0$, the interaction is bonding, while $\lambda_{2}>0$, the interaction is nonbonding [23]. According to the above three properties of the electron density, three main types of noncovalent interactions: attractive, moderately strong (e.g., hydrogen bonds), repulsive, moderately strong (e.g., steric interactions), and weak dispersion type interactions were identified. The $\operatorname{Sign}(\lambda) \rho-\operatorname{RDG}(\mathrm{r})$, and the color-filled graph of weak interaction regions $\left(\operatorname{Sign}\left(\lambda_{2}\right) \rho-\mathrm{RDG}(\mathrm{r})\right.$ isosurface) of $\mathrm{Cu}\left[\mathrm{Tf}_{2} \mathrm{~N}\right]-$ $\mathrm{C}_{3} \mathrm{H}_{8}$, and $\mathrm{Cu}\left[\mathrm{Tf}_{2} \mathrm{~N}\right]-\mathrm{C}_{3} \mathrm{H}_{6}$ were depicted in Fig. 3 and Fig. 4.

The weak interactions always exist in the place of small $\rho(\mathrm{r})$ and 0 $\sim$ medium RDG(r). The scatter diagrams of $\rho(\mathrm{r})-\mathrm{RDG}(\mathrm{r})$ are helpful for notarizing the existence of weak interactions. The subsistent splattering area of small $\rho(\mathrm{r})$ and $0 \sim$ medium RDG(r) was addressed as "spike", and it accounts for the existence of weak interactions in the complex [22]. It can be found that plots of the electron density $(\rho)$ and its reduced density gradient for $\mathrm{Cu}\left[\mathrm{Tf}_{2} \mathrm{~N}\right]-$ $\mathrm{C}_{3} \mathrm{H}_{8}$ and $\mathrm{Cu}\left[\mathrm{Tf}_{2} \mathrm{~N}\right]-\mathrm{C}_{3} \mathrm{H}_{6}$ have "spikes", suggesting the occurrence of weak interactions. In order to classify the types of weak interactions, the scatter diagrams of $\operatorname{Sign}\left(\lambda_{2}\right) \rho-\mathrm{RDG}(\mathrm{r})$ for $\mathrm{Cu}\left[\mathrm{Tf}_{2} \mathrm{~N}\right]-\mathrm{C}_{3} \mathrm{H}_{8}$ and $\mathrm{Cu}\left[\mathrm{Tf} \mathrm{N}_{2} \mathrm{~N}-\mathrm{C}_{3} \mathrm{H}_{6}\right.$ were depicted. Large, negative values of $\operatorname{sign}\left(\lambda_{2}\right)$ are indicative of hydrogen bonding interactions, values near zero indicate van der Waals interactions, and large and positive $\operatorname{sign}\left(\lambda_{2}\right)$ the steric effect. The hydrogen bonds, van der Waals interactions and steric effect occur, but the steric effect of $\mathrm{Cu}\left[\mathrm{Tf} \mathrm{N}_{2}\right]-\mathrm{C}_{3} \mathrm{H}_{6}$ was weaker than that of $\mathrm{Cu}\left[\mathrm{Tf}_{2} \mathrm{~N}\right]-\mathrm{C}_{3} \mathrm{H}_{8}$. The gradient isosurfaces (Fig. 3) provide a rich visualization of weak interactions as broad regions of real space, rather than simple pairwise contacts between atoms. In the weak interaction pictures, the different interactions between $\mathrm{Cu}\left[\mathrm{Tf}_{2} \mathrm{~N}\right]$ and $\mathrm{C}_{3} \mathrm{H}_{8} / \mathrm{C}_{3} \mathrm{H}_{6}$ are apparent. In $\mathrm{Cu}\left[\mathrm{Tf}_{2} \mathrm{~N}\right]-\mathrm{C}_{3} \mathrm{H}_{8}$, the attractive interaction, weak interaction and steric effect exist, while the strong interaction (covalent interactions) between $\mathrm{Cu}\left[\mathrm{Tf}_{2} \mathrm{~N}\right]$ and $\mathrm{C}_{3} \mathrm{H}_{8}$ occur, giving rise to the strong interaction energy.

Dapprich, and Frenking [24] put forward a partitioning scheme for analyzing donor-acceptor interactions in a complex. The charge decomposition analysis constructs the wave function of the complex in terms of the linear combination of the donor and acceptor fragment orbitals (LCFO). Three terms, the charge donation $d$, the back donation $b$, and the charge depletion from the overlapping area (charge polarization) $r$ were calculated for each LCFO orbital of the complex. The sum of the three contributions gives the total amount of donation, back donation and charge polarization in the complex. The number of electrons donated from $\mathrm{Cu}\left[\mathrm{Tf}_{2} \mathrm{~N}\right]$ to $\mathrm{C}_{3} \mathrm{H}_{8} / \mathrm{C}_{3} \mathrm{H}_{6}$ (d), the number of electrons back donated from $\mathrm{C}_{3} \mathrm{H}_{8} / \mathrm{C}_{3} \mathrm{H}_{6}$ to $\mathrm{Cu}\left[\mathrm{Tf}_{2} \mathrm{~N}\right]$ (b), and the number of electrons involved in repulsive polarization (r) are listed in Table 4. It can be seen that the weak electron donation $\mathrm{Cu}\left[\mathrm{Tf}_{2} \mathrm{~N}\right]-\mathrm{C}_{3} \mathrm{H}_{8}(0.0054 \mathrm{e})$ and strong back donation $\mathrm{C}_{3} \mathrm{H}_{8}-\mathrm{Cu}\left[\mathrm{Tf}_{2} \mathrm{~N}\right](0.1341 \mathrm{e})$ occur, while the net charge transfer from $\mathrm{Cu}\left[\mathrm{Tf}_{2} \mathrm{~N}\right]$ to $\mathrm{C}_{3}^{3} \mathrm{H}_{6}$ is 0.761 . The calculated charge polarization is quite different, It is -0.117 e for $\mathrm{Cu}\left[\mathrm{Tf}_{2} \mathrm{~N}\right]-\mathrm{C}_{3} \mathrm{H}_{8}$ and -0.082 e for $\mathrm{Cu}\left[\mathrm{Tf}_{2} \mathrm{~N}\right]-\mathrm{C}_{3} \mathrm{H}_{6}$, respectively. 


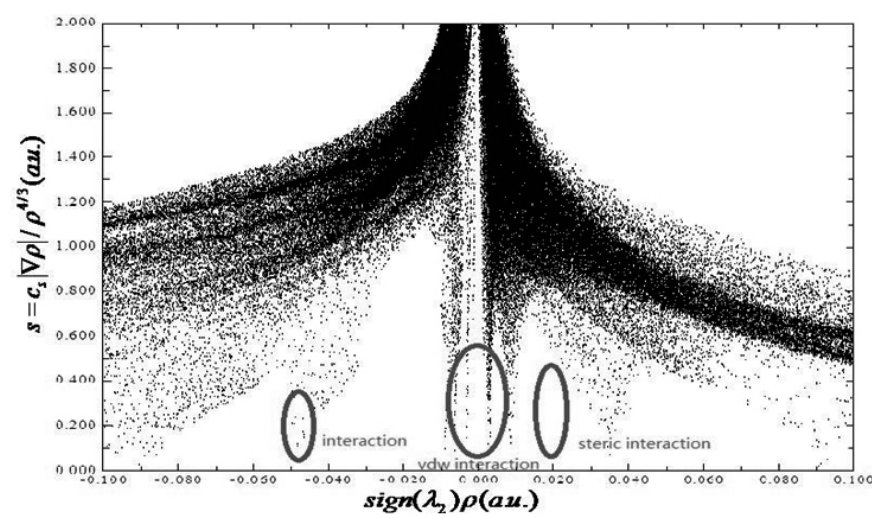

(a)

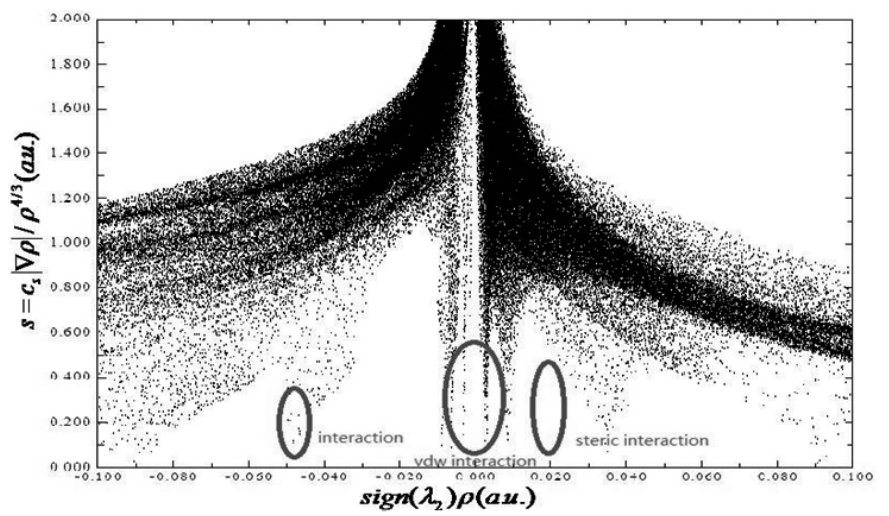

(b)

Fig. 3 Plots of the reduced density gradient versus the electron density multiplied by the sign of the second Hessian eigenvalue. (a) $\mathrm{Cu}\left[\mathrm{Tf}_{2} \mathrm{~N}\right]-\mathrm{C}_{3} \mathrm{H}_{8}$ and (b) $\mathrm{Cu}\left[\mathrm{Tf}_{2} \mathrm{~N}\right]-\mathrm{C}_{3} \mathrm{H}_{6}$
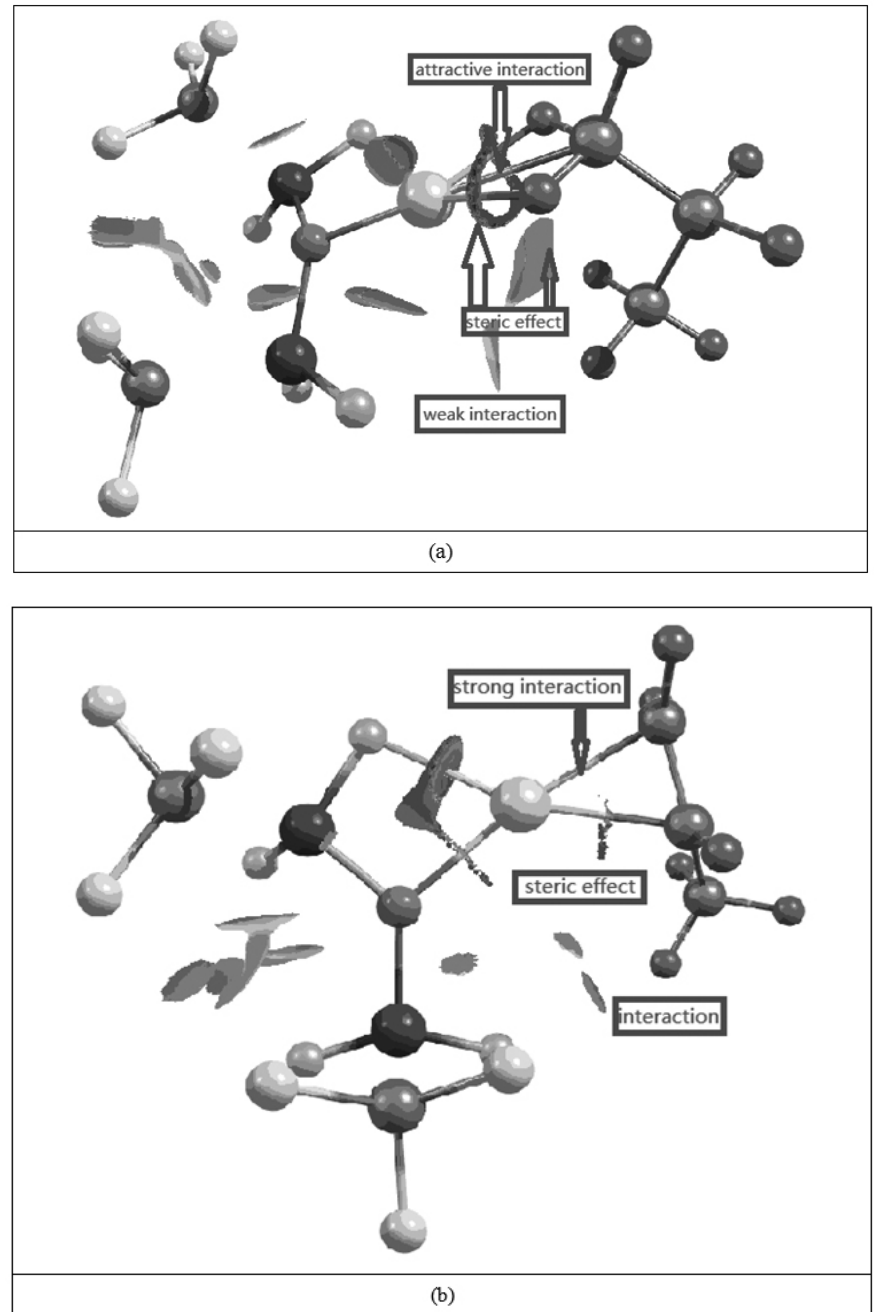

Fig. 4 Plots of gradient isosurfaces for (a) $\mathrm{Cu}\left[\mathrm{Tf}_{2} \mathrm{~N}\right]-\mathrm{C}_{3} \mathrm{H}_{8}$ and (b) $\mathrm{Cu}\left[\mathrm{Tf}_{2} \mathrm{~N}\right]-\mathrm{C}_{3} \mathrm{H}_{6}$

Table 4 The number of electrons donated from $\mathrm{Cu}\left[\mathrm{Tf}_{2} \mathrm{~N}\right]$ to $\mathrm{C}_{3} \mathrm{H}_{8} / \mathrm{C}_{3} \mathrm{H}_{6}$ (d), the number of electrons back donated from $\mathrm{C}_{3} \mathrm{H}_{8} / \mathrm{C}_{3} \mathrm{H}_{6}$ to $\mathrm{Cu}\left[\mathrm{Tf} f_{2} \mathrm{~N}\right](\mathrm{b})$, and the number of electrons involved in repulsive polarization (r)

\begin{tabular}{|c|c|c|c|c|}
\hline & $\mathrm{d}$ & $\mathrm{b}$ & \multirow{2}{*}{$\mathrm{d}-\mathrm{b}$} \\
\cline { 2 - 5 } & $\mathrm{Cu}\left[\mathrm{Tf}_{2} \mathrm{~N}\right] \rightarrow \mathrm{C}_{3} \mathrm{H}_{8} / \mathrm{C}_{3} \mathrm{H}_{6}$ & $\mathrm{Cu}\left[\mathrm{Tf}_{2} \mathrm{~N}\right] \leftarrow \mathrm{C}_{3} \mathrm{H}_{8} / \mathrm{C}_{3} \mathrm{H}_{6}$ & \\
\hline $\mathrm{Cu}\left[\mathrm{Tf}_{2} \mathrm{~N}\right]-\mathrm{C}_{3} \mathrm{H}_{8}$ & 0.005403 & 0.134097 & -0.128694 & -0.117491 \\
\hline $\mathrm{Cu}\left[\mathrm{Tf}_{2} \mathrm{~N}\right]-\mathrm{C}_{3} \mathrm{H}_{6}$ & -0.048576 & -0.809535 & 0.760959 & -0.082345 \\
\hline
\end{tabular}

The density difference can be employed to locate ranges of charge depletion and charge concentration. A related scheme uses the calculation of the Laplacian $\nabla^{2} \rho(r)$ of the density distribution $\rho(r)$, which determines the regions in space wherein electronic charge is locally concentrated and depleted. The electron density differences of $\mathrm{Cu}\left[\mathrm{Tf}_{2} \mathrm{~N}\right]-\mathrm{C}_{3} \mathrm{H}_{8}$ and $\mathrm{Cu}\left[\mathrm{Tf}_{2} \mathrm{~N}\right]-\mathrm{C}_{3} \mathrm{H}_{6}$ shown in Fig. 5 reflect the redistribution of electron. It can be found that the electronic charge between two hydrogen atoms is depleted and electronic charge of the two $\sigma^{*}(\mathrm{C}-\mathrm{H})$ is concentrated in $\mathrm{Cu}\left[\mathrm{Tf}_{2} \mathrm{~N}\right]-\mathrm{C}_{3} \mathrm{H}_{8}$. The depletion of electronic charge of $\pi$ orbital in $\mathrm{C}_{3} \mathrm{H}_{6}$ and d orbital of $\mathrm{Cu}$, the concentration of electronic charge of $\pi^{*}$ orbital in $\mathrm{C}_{3} \mathrm{H}_{6}$ demonstrate the charge transfer from $\pi$ orbital in $\mathrm{C}_{3} \mathrm{H}_{6}$ to $4 \mathrm{~s}^{*}$ orbital of $\mathrm{Cu}$, and back donation from $\mathrm{d}$ orbital of $\mathrm{Cu}$ to $\pi^{*}$ orbital in $\mathrm{C}_{3} \mathrm{H}_{6}$, in agreement with the $\mathrm{NBO}$ analysis. 

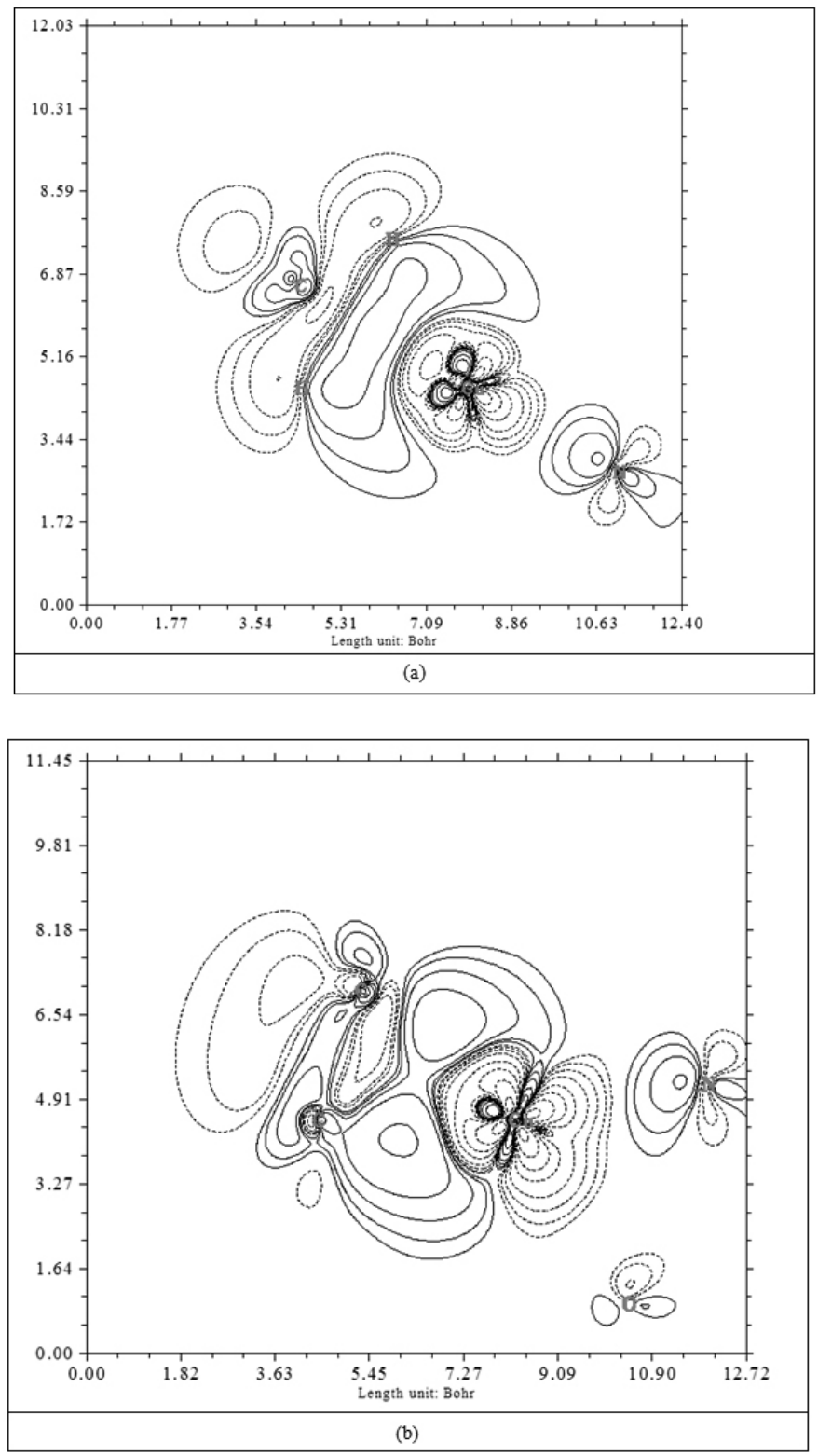

Fig. 5 The electron density difference of (a) $\mathrm{Cu}\left[\mathrm{Tf}_{2} \mathrm{~N}\right]-\mathrm{C}_{3} \mathrm{H}_{8}$, and (b) $\mathrm{Cu}\left[\mathrm{Tf}_{2} \mathrm{~N}\right]-\mathrm{C}_{3} \mathrm{H}_{6}$

\section{CONCLUSIONS}

The molecular structures and nature of interactions between copper(I) bis(trifluoromethylsulfonyl)imide $\left(\mathrm{Cu}\left[\mathrm{Tf}_{2} \mathrm{~N}\right]\right)$ and $\mathrm{C}_{3} \mathrm{H}_{8} / \mathrm{C}_{3} \mathrm{H}_{6}$ were investigated on the basis of ab initio method. The most stable structures of $\mathrm{Cu}\left[\mathrm{Tf}_{2} \mathrm{~N}\right]-\mathrm{C}_{3} \mathrm{H}_{8}$ and $\mathrm{Cu}\left[\mathrm{Tf}_{2} \mathrm{~N}\right]-\mathrm{C}_{3} \mathrm{H}_{6}$ indicate the significant differences between $\mathrm{Cu}\left[\mathrm{Tf}_{2} \mathrm{~N}\right]$ and $\mathrm{C}_{3} \mathrm{H}_{8} / \mathrm{C}_{3} \mathrm{H}_{6}$. The nature of interactions between $\left.\mathrm{Cu}\left[\mathrm{Tf}_{2} \mathrm{~N}\right]\right)$ and $\mathrm{C}_{3} \mathrm{H}_{8} / \mathrm{C}_{3} \mathrm{H}_{6}$ were investigated by NBO analysis, charge decomposition analysis, and analyses of weak interactions with several real space functions, demonstrating the formation of chemical bonds between $\mathrm{Cu}\left[\mathrm{Tf}_{2} \mathrm{~N}\right]$ and $\mathrm{C}_{3} \mathrm{H}_{6}$. The remarkably different interaction energies between $\mathrm{Cu}\left[\mathrm{Tf}_{2} \mathrm{~N}\right]$ and $\mathrm{C}_{3} \mathrm{H}_{8} / \mathrm{C}_{3} \mathrm{H}_{6}$ imply that $\mathrm{Cu}\left[\mathrm{Tf}_{2} \mathrm{~N}\right]$ ionic liquid may be used to separate $\mathrm{C}_{3} \mathrm{H}_{8} / \mathrm{C}_{3} \mathrm{H}_{6}$ mixture.

\section{ACKNOWLEDGMENTS}

The authors gratefully acknowledge financial support from the Natural Science Foundation of Shandong Province (ZR2013BM028).

\section{REFERENCES}

[1] Friederike Agel, Fee Pitsch, Florian Felix Krull, Peter Schulz,Matthias Wessling, Thomas Melinb, Peter Wasserscheida, Phys. Chem. Chem. Phys. 13, 725, (2011)

[2] A. Ortiz, A. Ruiz, D. Gorri, I. Ortiz, Sep. Purif. Technol. 63, 311, (2008)

[3] A. Ortiz, L.M. Galán Sanchez, D. Gorri, A.B. De Haan, I. Ortiz, Ind. Eng. Chem. Res. 49, 7227, (2010)

[4] A. Ortiz, L.M. Galán, D. Gorri, A. B. De Haan, I. Ortiz, Sep. Purif. Technol. 73, 106, (2010)

[5] A. Ortiz, D. Gorri, A. Irabien, I. Ortiz, J. Membrane Sci. 360, 130, (2010)

[6] M. Fallanza, A. Ortiz, D. Gorri, I. Ortiz, Desalin. Water Treat. 27, 123, (2011)

[7] M. Fallanza, A. Ortiz, D. Gorri, I. Ortiz, Sep. Purif. Technol. 97, 83, (2012)

[8] M. Stricker, B. Oelkers, C. P. Rosenau, J. Sundermeyer. Chem. Eur. J. 19, $1042,(2013)$

[9] O. G. Polyakov, S. M. Ivanova, C. M. Gaudinski, S. M. Miller, O. P. Anderson, S. H. Strauss, Organometallics 18, 3769, (1999)

[10]A. Vij, Y. Y. Zheng, R. L. Kirchmeier, J. M. Shreeve, Inorg. Chem. 33, $3281,(1994)$

[11]F. Pitsch, F. F. Krull, F. Agel, P. Schulz, P. Wasserscheid, T. Melin, M. Wessling, Adv. Mater. 24, 4306, (2012)

[12] L. M. Galan Sanchez, G. Wytze Meindersma, A. B. Haan, Ind. Eng. Chem. Res. 48, 10650, (2009)

[13]X. Xu, W.A. Goddard III, Proc. Natl. Acad. Sci. 101, 2673, (2004)

[14]J. Pernak, R. Kordala, B. Markiewicz, F.Walkiewicz, M. Poplawski, A. Fabianska, S. Jankowski, M. Lozynski, RSC Adv. 2, 8429, (2012)

[15]S. Chen, R. Vijayaraghavan, D.R. MacFarlane, E.I. Izgorodina, J. Phys. Chem. B 117, 3186, (2013)

[16] X. Xu, Q. Zhang, R. P. Muller, W.A. Goddard III, J. Chem. Phys. 122, 014105, (2005)

[17]R. F. W. Bader, Chem. Rev. 91, 893, (1991)

[18] T. Lu, F. Chen, J. Mol. Graph. Model. 38, 314, (2012)

[19] T. Lu, F. Chen, J. Comput. Chem. 33, 580, (2012)

[20] S. F. Boys, F. Bernardi, Mol. Phys. 19, 553, (1970)

[21]A. Bondi, J. Phys. Chem. 68, 441, (1964)

[22]E. R. Johnson, S. Keinan, P. Mori-Sanchez, J. Contreras-Garcia, A. J. Cohen, W. Yang, J. Am. Chem. Soc. 132, 6498, (2010)

[23] R. F. W. Bader, Chem. Rev. 91, 893 (1991)

[24] S. Dapprich, G. Frenking, J. Phys. Chem. 99, 9352, (1995) 